
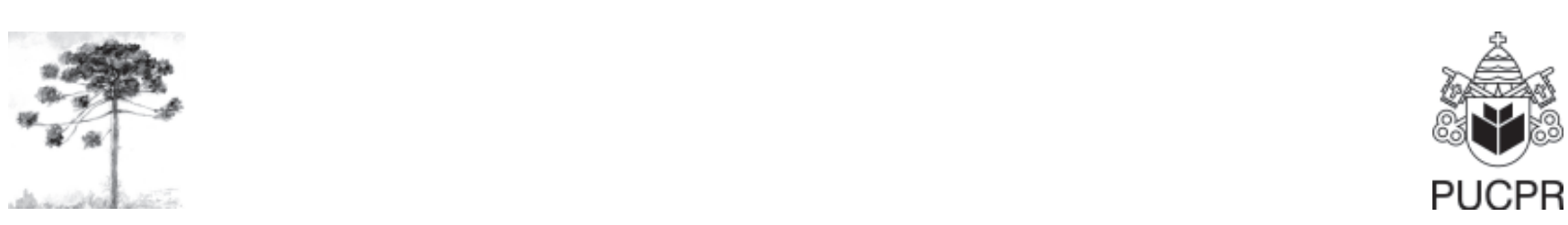

\title{
TOTAL AND FECAL COLIFORMS CONTAMINATION IN FAUCETS AND FLUSH BOTTOMS IN PUBLIC WASHROOMS SITED IN SHOPPING MALLS OF CURITIBA, STATE OF PARANA, BRAZIL
}

Contaminação por coliformes totais e fecais em torneiras e válvulas de descarga de banheiros públicos localizados em shoppings centers de Curitiba, Estado do Paraná, Brasil

\author{
Janaína Capelli Peixoto ${ }^{[1]}$, Sérgio Eduardo Fontoura-da-Silva ${ }^{[2]}$
}

[1] Acadêmica do Curso de Biologia da Pontifícia Universidade Católica do Paraná (PUCPR), Curitiba, PR - Brasil. ${ }^{[2]}$ Professor do Curso de Farmácia da Pontifícia Universidade Católica do Paraná (PUCPR), Curitiba, PR - Brasil, e-mail: sergio.f@pucpr.br

\begin{abstract}
A study was performed regarding the presence of fecal coliforms in faucets and flush bottoms in public restrooms in 10 shopping malls of Curitiba, Paraná, Brazil. The presence of these bacteria shows fecal contamination. Escherichia coli is the prototype of fecal coliforms that was found in $13,1 \%$ of the samples, being more common on faucets $(21.9 \%)$ than on flush bottoms (4.6\%), this difference was significant. Other enterobacteria have been found: Enterobacter agglomerans, Enterobacter sakazakii, Klebsiella oxytoca, Providencia alcafaciens, Providencia rettgeri and Serratia liquefaciens. These bacteria do not necessarily indicate fecal contamination. Nonfermentative gram negative bacilli (NFGNB) were found in 25 samples $(43,9 \%)$, being more common over the flush bottoms $(39,5 \%)$. The presence of fecal coliforms may indicate imperfection in the hygienic cleaning in these places, compromising the health of its users.
\end{abstract}

Keywords: Shopping mall; Restrooms; Fecal Coliforms; Escherichia coli; NFGNB. 


\section{Resumo}

Foi realizado um estudo quanto à presença de coliformes fecais nas torneiras e válvulas de descarga de banheiros localizados em 10 shopping centers da cidade de Curitiba. A presença dessas bactérias indica contaminação fecal. A Escherichia coli, o protótipo dos coliformes fecais, foi encontrada em 21,9\% das amostras, sendo mais comum nas torneiras (21,9\%) do que nas válvulas de descarga $(4,6 \%)$, essa diferença foi significativa $\left(c^{2}{ }_{1}=4,10 ; p<0,05\right)$. Também foram encontradas outras enterobactérias: Enterobacter agglomerans, Enterobacter sakazakii, Klebsiella oxytoca, Providencia alcafaciens, Providencia rettgeri $e$ Serratia liquefaciens, que não indicam, necessariamente, contaminação fecal. Também foram encontrados bacilos gram negativos não fermentadores da glicose (BGNNF) em 25 amostras (43,9\%). A presença de coliformes fecais pode indicar falha na higienização destes espaços, comprometendo a saúde de seus usuários.

Palavras-chave: Shopping center; Banheiros públicos; Escherichia coli; Coliformes fecais; BGNñF.

\section{INTRODUCTION}

Public Restrooms are places where people in transit help themselves to satisfy their physiological needs. However, they don't always find hygiene and cleanliness in these locations, which are breeding microorganisms. About $25 \%$ of people leave these locations carrying fecal coliforms (1).

According to the Department of Public Health of Massachusetts (2), washing hands properly is the best way to prevent the development of infections. Varella (3) also agrees and says that a measure so simple has great importance in public health. For him, the act of washing hands would decrease, among other diseases, the mortality rate of babies by diarrhea in children throughout the country. The act of drying hands is as important as washing them. In public restrooms you can dry them with paper towels, cloth towels, or a jet of hot air.

The Enterobacteriaceae family is composed of enterobacteria, or enteric bacteria, which is a group of gram-negative and not sporulated bacilli, with variable motility, negative oxidase, and that grow up in basic solution (peptone solution), rich medium (blood agar, chocolate agar), or selective solutions (MacConkey, EMB). These bacteria are facultative anaerobic, that ferment glucose producting or not gas, are positive catalase and reduce the nitrate to nitrite (4).
Some enterobacteria are potentially patogenics to human being. Because of its ubiquity inside and outside the body, they can cause opportunistic infections in weakened people (5).

According to Levy (4), the clinical importance of the enterobacteria is that they are responsible for about $70 \%$ of urinary infections and $50 \%$ of sepsis. The presence of fecal coliforms is used as an indicator of fecal contamination, or inadequate health care and hygienic conditions. The main representative of this group is Escherichia coli, which has its unique habitat in the intestinal tract of man and of warm-blooded animals $(6,7,8)$.

The contamination by E. coli occurs orally, mainly through water and food contaminated with fecal material (8). Infected individuals are also sources of contamination, because the bacteria may be present in their hands (9). Other sources of contamination would be potentially unhealthy places such as public restrooms, giving the importance of this research.

The E. colicauses often, in healthy individuals, urinary infections and gastroenteritis. Some capsulated strains of these bacteria may be associated with the development of neonatal meningitis (5).

The main purpose of this study was to verify the presence of fecal coliforms on discharge valves and faucets in public restrooms, located in malls in Curitiba. To investigate the existence of other enterobacteria; to compare the contamination among the places searched and propose ways to reduce the possibility of contagion. 


\section{MATERIAL AND METHODS}

The samples were collected in September 2007, in 10 malls of Curitiba, Parana, Brazil. On them, microbiological material was collected from the discharge valves and faucets, randomly chosen. Before the sampling, the supervisor for the establishment was consulted beforehand by email and/or letter, making clear that both his and the mall's name would be kept confidential.

In the chosen restroom the sample was taken in $50 \%$ of discharge valves and $50 \%$ of faucets, also chosen randomly. A wooden rod swab moistened with sterile saline was rubbed on each of the areas, where the users of this restrooms should touch, and immediately dipped into a sterile tube containing BHI (Brain Heart Infusion) broth, which was quickly transported in a Styrofoam container to the laboratory of microbiology of PUCPR where it was investigated. When the men's restroom was chosen, the sample was collected in the presence of the supervisor for the respective restroom.

The identification of coliform was made using modifications, the procedure described by Cardoso (8) as follows.

In the laboratory, the tubes of BHI used in the collect were brooded in a bacteriological stove at $37 \mathrm{C}$ for $24 \mathrm{~h}$. After this period, the tubes that were muddy were transplanted by depauperation to the MacConkey agar. The tubes that remained clear were kept in the stove for another $24 \mathrm{~h}$. After 48 hours, if they wouldn't show depauperation by eyesight, the tubes would be disregarded and their samples consider as negatives.

After the transplatation to MacConkey agar, the plates were brooded in a bacteriological stove for $24 \mathrm{~h}$ at $37 \mathrm{C}$ and after this period the fermentative colonies of lactose $(\mathrm{lac}+)$ were transplanted to the mini-kit tubes for the enterobacteria identification (Newprov). Despite of fecal coliform being the fermentative bacteria of lactose, the colonies non-fermentative of lactose (lac-) were also considered in this study.

Mini kits were brooded in a bacteriological stove for $24 \mathrm{~h}$ and after this period, was held the reading of the results, based on the Enterobacteria Identification Manual (10).

For ethical issues, the establishments visited were identified by Roman numerals I to X, the discharge valves by the initials DV and faucets by the letter F.

The statistical tests needed, for comparison purposes, description of the malls, faucets and discharge valves were made using the computer program BioEstat 2.0 developed by Ayres et al. (11).

\section{RESULTS AND DISCUSSION}

Of the 10 malls, 84 samples were taken, and 43 were from the discharge valves and 41 from faucets. The findings were 4 outbreaks of Enterobacter agglomerans, 2 of Eneterobacter sakazakii, 11 of Escherichia coli, 1 of Klebsiella oxytoca, 4 of Providencia alcalifaciens, 2 of Providencia rettgeri, and 8 of Serratia liquefaciens. Plus there was 25 bacilli gram negative nonfermentative of glucose. All pipes have BHI broth turbidity apparent, however, 27 samples showed up negative - no bacterial colonies had grown in MacConkey agar (Table 1).

E. coli, the prototype of fecal coliforms, was present on 9 samples from faucets $(21,9 \%)$ and in 2 discharge valves $(4,6 \%)$. This difference was significant $(\mathrm{p}<0,05)$. The presence of NFGNB was observed in 8 samples $(19,5 \%)$ from faucets and $17(39,5 \%)$ from discharge valves. This difference also showed up relevant $(\mathrm{p}<0,05)$. The Tables 2 and 3 describe the observed rates of E. coli and other enterobacteria and NFGNB.

The fact that there is no contact the hands with the discharge valve, after which the use of the toilet can be pressed with toilet paper, with an elbow or toes, is a possible explanation for the significant difference found in the frequencies of E. coli in faucets and discharge valves. Or, people press the discharge valve before the intimate hygiene, after using the restroom and then wash the hands, contaminating the faucets as they touch them. Still, a small percentage of users will not trigger the discharge, as informed by the responsibles of the restrooms searched. 
TABLE 1 - Bacteria found on the collect places

\begin{tabular}{|c|c|c|c|c|c|c|}
\hline \multirow{3}{*}{ RESULTS } & \multicolumn{6}{|c|}{ COLLECT PLACES } \\
\hline & \multicolumn{2}{|c|}{ F } & \multicolumn{2}{|c|}{ DV } & \multicolumn{2}{|c|}{ Total } \\
\hline & $\mathbf{N}^{\mathbf{o}}$ & $\%$ & $\mathbf{N}^{\mathbf{o}}$ & $\%$ & $\mathbf{N}^{\mathbf{o}}$ & $\%$ \\
\hline Escherichia coli & 9 & 21,9 & 2 & 4,6 & 11 & 13,0 \\
\hline Enterobacter agglomerans & 1 & 2,4 & 3 & 6,9 & 4 & 4,8 \\
\hline Enterobacter sakazakii & 2 & 4,8 & 0 & 0,0 & 2 & 2,4 \\
\hline Klebsiella oxytoca & 0 & 0,0 & 1 & 2,3 & 1 & 1,2 \\
\hline Providencia alcalifaciens & 2 & 4,8 & 2 & 4,6 & 4 & 4,8 \\
\hline Providencia rettgeri & 1 & 2,4 & 1 & 2,3 & 2 & 2,4 \\
\hline Serratia liquefaciens & 5 & 12,0 & 3 & 6,9 & 8 & 9,6 \\
\hline NFGNB & 8 & 19,2 & 17 & 39,1 & 25 & 18,0 \\
\hline Negative & 13 & 32,5 & 14 & 33,3 & 27 & 43,8 \\
\hline Total & 41 & 48,8 & 43 & 51,2 & 84 & 100,0 \\
\hline
\end{tabular}

TABLE 2 - Bacteria found in malls without distinction of the collect places

\begin{tabular}{|c|c|c|c|c|c|c|c|c|c|c|}
\hline \multirow{3}{*}{ Malls } & \multicolumn{10}{|c|}{ RESULTADOS } \\
\hline & \multicolumn{2}{|c|}{ E.coli } & \multicolumn{2}{|c|}{$\begin{array}{c}\text { Other } \\
\text { Enterobacterias }\end{array}$} & \multicolumn{2}{|c|}{$\begin{array}{c}\text { Non- } \\
\text { Fermentative }\end{array}$} & \multicolumn{2}{|c|}{ Negatives } & \multicolumn{2}{|c|}{ Total } \\
\hline & $\mathbf{N}$ & $\%$ & $\mathbf{N}$ & $\%$ & $\mathbf{N}$ & $\%$ & $\mathbf{N}$ & $\%$ & $\mathbf{N}$ & $\%$ \\
\hline I & 1 & 11,1 & 4 & 44,4 & 3 & 33,3 & 1 & 11,1 & 9 & 10,7 \\
\hline II & 0 & 0,0 & 0 & 0,0 & 2 & 28,6 & 5 & 71,4 & 7 & 8,3 \\
\hline III & 2 & 18,2 & 2 & 18,2 & 3 & 27,3 & 4 & 36,4 & 11 & 13,1 \\
\hline IV & 1 & 11,1 & 1 & 11,1 & 4 & 44,4 & 3 & 33,3 & 9 & 10,7 \\
\hline $\mathrm{V}$ & 1 & 10,0 & 5 & 50,0 & 2 & 20,0 & 2 & 20,0 & 10 & 11,9 \\
\hline VI & 2 & 22,2 & 2 & 22,2 & 4 & 44,4 & 1 & 11,1 & 9 & 10,7 \\
\hline VII & 1 & 16,7 & 2 & 33,3 & 1 & 16,7 & 2 & 33,3 & 6 & 7,1 \\
\hline VIII & 2 & 28,6 & 2 & 28,6 & 3 & 42,8 & 0 & 0,0 & 7 & 8,3 \\
\hline IX & 0 & 0,0 & 3 & 30,0 & 2 & 20,0 & 5 & 50,0 & 10 & 11,9 \\
\hline $\mathrm{X}$ & 1 & 16,7 & 0 & 0,0 & 1 & 16,7 & 4 & 66,7 & 6 & 7,1 \\
\hline Total & 11 & 13,1 & 21 & 25,0 & 25 & 29,8 & 27 & 32,1 & 84 & 100,0 \\
\hline
\end{tabular}

TABLE 3 - Bacteria found at the sampling locations without distinction of the mall

\begin{tabular}{|c|c|c|c|c|c|c|c|c|c|c|}
\hline \multirow{3}{*}{$\begin{array}{r}\text { Collect } \\
\text { Places }\end{array}$} & \multicolumn{10}{|c|}{ RESULTS } \\
\hline & \multicolumn{2}{|c|}{ E.coli } & \multicolumn{2}{|c|}{$\begin{array}{c}\text { Other } \\
\text { Enterobacterias }\end{array}$} & \multicolumn{2}{|c|}{$\begin{array}{l}\text { Non- } \\
\text { Fermentative }\end{array}$} & \multicolumn{2}{|c|}{ Negatives } & \multicolumn{2}{|c|}{ Total } \\
\hline & $\mathbf{N}$ & $\%$ & $\mathbf{N}$ & $\%$ & $\mathbf{N}$ & $\%$ & $\mathbf{N}$ & $\%$ & $\mathbf{N}$ & $\%$ \\
\hline $\mathrm{F}$ & 9 & 81,1 & 11 & 52,4 & 8 & 32,0 & 13 & 48,8 & 41 & 48,8 \\
\hline VD & 2 & 18,2 & 10 & 47,6 & 17 & 68,0 & 14 & 51,9 & 13 & 51,2 \\
\hline Total & 11 & 13,0 & 21 & 25,0 & 25 & 29,8 & 27 & 32,1 & 84 & 100,0 \\
\hline
\end{tabular}


As it was not objective of this paper, the identification of the NFGNB, it was not conducted using specific kits, however, one of the samples showed growth in MacConkey agar of colonies compatible with Pseudomonas aeroginosa (greenish colonies with characteristic odor).

Pseudonomas are ubiquos microorganisms found in soil, in decomposing organic matter, vegetation and water. They are also found in hospital environments, in wet reservoirs such as food, cut flowers, sinks, toilets, mops, and equipment for respiratory treatment and even in disinfectant solutions (12).

The greater frequency of NFGNB on discharge valves, may mean that people already entered in the bathrooms with their hands contaminated with microorganisms, from buses among other locations, or perhaps is the fact that the person responsible for cleaning the place does so with contaminated clothing or solutions and more repeatedly in the sinks and faucets because this act is visible to visitors, while in the toilets, the clean rapidly, collecting the trash and not worrying about cleaning the discharge valve itself, perhaps from a lack of information.

On 27 samples $(43,8 \%)$ there was no growth in MacConkey agar despite the presence of turbidity in BHI broth. This may mean that in those samples there were some microorganims that do not grow in this enviroment, as gram positive bacterias or some NFGNB.

\section{CONCLUSION}

It was expected to find greater number of these environmental bacteria (those that are everywhere and do not cause damage to human health in normal individuals) than the fecal ones, which besides being highly pathogenic, they are, according to Levy (4) (2004) most commonly found in clinic samples and hospital infections. He has proved that the predominants are the $E$. coli, Klebsiella spp. and Enterobacter spp.. And also in about $99 \%$ of the insulation of enterobacteria in clinical samples, there are present E. coli, Klebsiella spp., Enterobacter spp., Proteus spp., Providencia spp., Morganella spp., Citrobacter., Salmonella spp., Shigella spp., and Serratia spp. Despite public restrooms being potentially unhealthy, the fecal bacterias would not survive very long outside their natural habitat. After collecting samples janitors were constantly cleaning the environment. The sinks and faucets were cleaned, in some malls, by cloths that were used also for cleaning the floor. If bacteria were present, they were in the presence of organic matter (possibly fecal).

Simple ways to reduce the transmission of bacterias would be washing hands and forearms, regularly, with soap and running water and anti sepsis with glicerinate soap containing alcohol $70 \%$, before accessing the doors to the toilets (destruction of the transitory flora). The discharge valves must be used with the lid of the toilet down, because the pressure of water causes the microbial spreads by air. Warnings of how to procede correctly when washing hands could be displayed on the walls of easy visible access. And it's necessary to clean the establishment with bactericidal products and it has to include the doorknobs, discharge valves, sinks and faucets, floors, walls and ceiling. Garbage cans should have a cover that would open through a valve, operated by foot.

\section{ACKNOWLEDGEMENT}

To Fernanda de Resende Gomes, the technician of the Laboratory of Microbiology I, whose support was important to conduct this research, those managers for the malls that authorized the collection as well the janitors of the restrooms, which have provided care and attention.

\section{REFERENCES}

1. Thomaz, VA. Abralimp alerta para cuidados na utilização dos banheiros públicos [citado 9 fev. 2007]. Disponível em: http://www.limp net.com.br/servicos/default11.asp

2. Massachusetts Department Of Public Health. [cited 15 fev. 2007]. Available from: http:// www.mass.gov/dph/cdc/handwashing/ factsheet_pt.htm

3. Varella D. Lavai as mãos: através delas transmitimos as piores infecções [citado 15 Aug]. Available at: http://drauziovarella.ig.com.br/ artigos/infeccoes.asp 
4. Levy CE. Manual de microbiologia clínica para o controle de infecção em serviços de saúde. ANVISA; Módulo V. 2004. [citado 15 fev. 2007]. Disponível em: http://www.anvisa.gov.br/ servicosaude/manuais / microbiologia/ introducao.pdf

5. García JMA, Bermejo CL. Infecciones por enterobacterias. Medicine. 1998;7(78):3622-8.

6. Rodrigues KL, Gomes JP, Conceição RCS, Brod CS, CarvalhaL JB, Aleixo AJG. Condições higiênico-sanitário no comércio ambulante de alimentos em Pelotas / RS. Ciênc Tecnol Alment. 2003;23(3):447-52.

7. Amson GV. Comércio ambulante de alimentos em Curitiba. Perfil de vendedores e propostas para programa de boas práticas higiênica na manipulação de alimentos [tese]. Curitiba: Universidade Federal do Paraná, Setor de Tecnologia, Programa de Pós-Graduação em Tecnologia de Alimentos; 2005 [citado 15 fev. 2007]. Disponível em: http://dspace.c3sl.ufpr.br/ dspace $/$ handle $/ 1884 / 1620$ ? mode $=$ simple

8. Cardoso BSA. Pesquisa microbiológica de coliformes fecais em mãos de manipuladores de alimentos de cantinas e restaurantes em uma Universidade de Curitiba-PR, Brasil [trabalho de conclusão de curso]. Curitiba: Pontifícia Universidade Católica do Paraná; 2007.
9. Evangelista J. Alimentos um estudo abrangente. São Paulo: Atheneu; 2002. p. 205-6.

10. Souza HAPHM. Manual de Identificação de Enterobactérias, Newprov Produtos para Laboratório. Pinhais: Newprov; 2006.

11. Ayres M, Ayres Jr. M, Ayres DL, Santos A. BioEstat 2.0: aplicações estatísticas nas áreas de ciências biológicas e médicas, Sociedade Civil Mamirauá-CNPq. Brasília: Lithera Maciel; 2000.

12. Menezes EA, Macedo FVV, Cunha FA, Andrade MSSM, Rocha VAP. Perfil de infecção e resistência aos antimicrobianos de bacilos Gram Negativos Não Fermentadores isolados no Laboratório de Patologia Clínica Dr. Edilson Gurgel, Santa Casa de Misericórdia de Fortaleza - Ceará. Rev Brás Anál Clin. 2004;36(4):209-12.
Received: 04/15/2007

Recebido: 15/04/2007

Approved: 06/20/2007 Aprovado: 20/06/2007 